\title{
Influence of different surface modification treatments on silk biotextiles for tissue engineering applications
}

\author{
Viviana P. Ribeiro, ${ }^{1,2}$ Lília R. Almeida, ${ }^{1,2}$ Ana R. Martins, ${ }^{1,2}$ Iva Pashkuleva, ${ }^{1,2}$ \\ Alexandra P. Marques, ${ }^{1,2}$ Ana S. Ribeiro, ${ }^{3}$ Carla J. Silva, ${ }^{3}$ Graça Bonifácio, ${ }^{4}$ Rui A. Sousa, ${ }^{1,2}$ \\ Rui L. Reis, ${ }^{1,2}$ Ana L. Oliveira ${ }^{1,2,5}$ \\ 13B's Research Group-Biomaterials, Biodegradables and Biomimetics, Universidade do Minho, Headquarters of the \\ European Institute of Excellence on Tissue Engineering and Regenerative Medicine, AvePark 4806-909, Caldas das Taipas, \\ Portugal \\ ${ }^{2}$ ICVS/3B's_PT Government Associated Laboratory, Braga, Guimarães, Portugal \\ ${ }^{3}$ CeNTI, Centre for Nanotechnology and Smart Materials, V.N. Famalicão, Portugal \\ ${ }^{4}$ CITEVE, Technological Centre for Textile and Clothing Industry, V.N. Famalicão, Portugal \\ ${ }^{5} \mathrm{CBOF}-$ Center for Biotechnology and Fine Chemistry, School of Biotechnology, Portuguese Catholic University, Porto \\ 4200-401, Portugal
}

Received 30 July 2014; revised 15 January 2015; accepted 19 February 2015

Published online 00 Month 2015 in Wiley Online Library (wileyonlinelibrary.com). DOI: 10.1002/jbm.b.33400

\begin{abstract}
Biotextile structures from silk fibroin have demonstrated to be particularly interesting for tissue engineering (TE) applications due to their high mechanical strength, interconnectivity, porosity, and ability to degrade under physiological conditions. In this work, we described several surface treatments of knitted silk fibroin (SF) scaffolds, namely sodium hydroxide $(\mathrm{NaOH})$ solution, ultraviolet radiation exposure in an ozone atmosphere $\left(\mathrm{UV} / \mathrm{O}_{3}\right)$ and oxygen $\left(\mathrm{O}_{2}\right)$ plasma treatment followed by acrylic acid (AAc), vinyl phosphonic acid (VPA), and vinyl sulfonic acid (VSA) immersion. The effect of these treatments on the mechanical properties of the textile constructs was evaluated by tensile tests in dry and hydrated states. Surface properties such as morphology,
\end{abstract}

topography, wettability and elemental composition were also affected by the applied treatments. The in vitro biological behavior of L929 fibroblasts revealed that cells were able to adhere and spread both on the untreated and surfacemodified textile constructs. The applied treatments had different effects on the scaffolds' surface properties, confirming that these modifications can be considered as useful techniques to modulate the surface of biomaterials according to the targeted application. (๑) 2015 Wiley Periodicals, Inc. J Biomed Mater Res Part B: Appl Biomater 00B: 000-000, 2015.

Key Words: silk fibroin, biotextile, surface modification, tissue engineering, scaffold

How to cite this article: Ribeiro VP, Almeida LR, Martins AR, Pashkuleva I, Marques, AP, Ribeiro AS, Silva CJ, Bonifácio Gc, Sousa RA, Reis RL, Oliveira AL 2015. Influence of different surface modification treatments on silk biotextiles for tissue engineering applications. J Biomed Mater Res Part B 2015:00B:000-000.

\section{INTRODUCTION}

The field of tissue engineering involves the use of scaffold materials that are ideally able to contribute to the necessary microenvironment for stimulating neo tissue morphogenesis. ${ }^{1,2}$ The combination of chemical, biological, and mechanical properties of the scaffold must provide instructive cues for cells to develop into a functional tissue in vivo. ${ }^{3-5}$ Three-dimensional (3D) polymeric structures are the main scaffolding materials in various tissue engineering approaches because of their versatility and the possibility of tailoring their properties.

Several strategies have been proposed to prepare polymeric porous 3D biodegradable scaffolds for tissue engineering (TE). ${ }^{1,6}$ Among these, fiber-based structures have demonstrated to be particularly interesting as they present higher porosity, interconnectivity and surface area, which can facilitate cellular attachment and consequently improve scaffold cell colonization and new tissue formation. $^{7-11}$ Textile technologies constitute an attractive route to develop fiber-based matrices. These technologies allow for the production at an industrial scale and they can offer a superior control over the material design (size, shape, porosity, and fiber orientation) and the manufacturing processing conferring a high degree of reproducibility without involving the use of toxic solvents. ${ }^{12-14}$ In particular,

Additional Supporting Information may be found in the online version of this article.

The FCT distinction attributed to A.L.

Correspondence to: A. L. Oliveira; e-mail: aloliveira@porto.ucp.pt

Contract grant sponsor: Portuguese Foundation for Science and Technology under POCTI and/or FEDER programs under the scope of the project TISSUE2TISSUE; contract grant number: PTDC/CTM/105703/2008

Contract grant sponsor: Investigator FCT program (to A.N.L.); contract grant number: IF/00411/2013 
knitting-based technologies are known to exhibit better extensibility or compliance as compared to other woven substrates, with an enhanced porosity/volume, although with limited thickness. ${ }^{15}$ In the literature, a few knitted structures from synthetic or natural materials have been already proposed, either alone ${ }^{16}$ or in a synergistic combination with other types of biomaterials/structures for the construction of functional 3D scaffolds, applicable in the repair/replacement and regeneration of tissues or organs such as blood vessels and heart valves, ${ }^{17-19}$ tendons and ligaments, ${ }^{17,20-25}$ cartilage, $^{26-28}$ and skin. ${ }^{29}$ As this is a new field of application for knitting technologies, most of these devices are still in exploratory stages. In this work, we have applied a knitting technology to fabricate highly reproducible biodegradable porous architectures using silk fibers. ${ }^{30}$

Silk fibroin (SF) is a natural protein that is spun into fibers by a variety of species including silkworms and spiders. ${ }^{31,32}$ This naturally occurring polymer has been clinically used as sutures for centuries. Long standing FDA regulatory approval of silk-based sutures, its abundance as raw fiber material and controlled proteolytic degradability in vitro and in vivo have established silk fibroin as a widely applied biomaterial. Moreover, silk-based biomaterials have been proposed for a range of tissue engineering applications, including bone, ${ }^{30,33,34}$ cartilage, ${ }^{35,36}$ tendon/ligament, ${ }^{37-40}$ and skin $^{41,42}$ regeneration. In all of these approaches, the use of silk fibroin is associated with targeted functional microenvironments supporting tissue morphogenesis.

SF is mainly composed by glycine and alanine and also contains significant quantities of serine, threonine, aspartic and glutamic acid, and tyrosine. ${ }^{43}$ The biomedical applications of SF can be broadened by chemical modifications, allowing for further biofunctionalization such as immobilization of growth factors or cell binding domains able to modulate cell behavior. ${ }^{32,44}$ There are several examples of SF matrices successfully modified by various surface treatments for advanced biological and therapeutic applications. ${ }^{45-50}$ Nonetheless, from those none involved a knitting processing technique combined with surface treatments. The main advantage of a surface modification is the possibility to alter the surface properties that indirectly dictate cell response, and at the same time preserve the bulk material features, such as, the mechanical properties and/or biodegradation. Polymeric scaffolds modified by radiofrequency (RF) argon plasma treatments have shown enhanced cell attachment, spreading and proliferation. ${ }^{45,46}$ Surface modifications of SF by plasma treatment using different working gases $\left(\mathrm{SO}_{2}, \mathrm{NH}_{3}\right.$, and $\left.\mathrm{O}_{2}\right)$ have demonstrated to increase the antithrombogenicity and the cellular activity of human epidermal keratinocytes and fibroblasts, suggesting that these structures might be potentially used as blood-contacting biomaterials or as novel extracellular matrices for other tissue engineering applications. ${ }^{47,48}$ Sulfonic acid is another compound recently used to tailor the surface chemistry of $\mathrm{SF}^{49,50}$ As a result of the introduced changes, SF decorated with sulfonated moieties could mimic the natural ECM environment and lead to further immobilization of biomolecules.
In the present study we explore several treatments to tailor the surface of SF knitted scaffolds: (i) wet chemical etching using $\mathrm{NaOH}$ (a method largely applied at the industrial scale, although not only surface confined); (ii) physical etching/oxidation (treatment with UV ozonator), which is better restricted to the surface; and (iii) the grafting of functional moieties after preactivation by plasma-this modification method is commonly applied for further biofunctionalization. We have chosen plasma among the possibilities for activation as it is very effective and the most surface confined modification method (few angstroms in depth). Additional, air plasma can be easily scaled-up; this versatile method can be used to easily decorate 3D scaffolds with various functional groups including sulfonic, phosphonic and carboxylic ones. This preliminary work reports on the effectiveness of the treatments and evaluates the effect of surface properties changes over early cell behavior. This study is a first step toward the development of surfaces that are able to easily bind to biomolecules that can stimulate ECM formation.

\section{MATERIALS AND METHODS}

\section{Production of the textile constructs and membranes}

Silk derived from silkworm Bombyxmori was used in the form of cocoons and yarns supplied by the Portuguese Association of Parents and Friends of Mentally Disable Citizens (APPA-CDM, Portugal). Plain 3D Jersey constructs were produced through weft knitting using the raw silk fibers (Tricolab machine, Sodemat, SA, Germany). The diameters of the fibers were measured and the average of five fibers calculated as $9.1 \pm 2.2 \mu \mathrm{m}$. The measured thickness of the silk textile matrix was $\sim 0.8 \mathrm{~mm}$. A detailed analysis of the 3D morphology of the textile constructs was previously performed through microcomputed tomography $(\mu \mathrm{CT}){ }^{30}$ The calculated average porosity, mean wall thickness, and mean pore size were $68.4 \pm 3.7 \%, 37.8 \pm 14.9 \mu \mathrm{m}$, and $54.5 \pm 9.4$ $\mu \mathrm{m}$, respectively.

Textile constructs were washed in a $0.15 \%(\mathrm{w} / \mathrm{v})$ natural soap aqueous solution for $2 \mathrm{~h}$ and then rinsed with distilled water. Silk structures underwent a subsequent purification process since Bombyxmori silkworm fibers are composed by a core protein called fibroin that is naturally coated by sericin, which is known to present cytotoxicity. ${ }^{51}$ Thus, SF textiles were consecutively boiled for $60 \mathrm{~min}$ in a $0.03 M$ sodium carbonate $\left(\mathrm{Na}_{2} \mathrm{CO}_{3}\right)$ solution and rinsed with distilled water to ensure the full extraction of the sericin.

Because some of the used characterization techniques [e.g., atomic force microscopy (AFM), contact angle] are better applied to 2D plan surfaces, SF membranes were also prepared and modified using the same procedures as the ones used for the textile constructs. SF membranes were cast from a water-based silk fibroin solution prepared as previously described by Yan et al. ${ }^{36}$ Briefly, the cocoons were consecutively boiled in an aqueous solution of $0.02 M$ sodium carbonate for $60 \mathrm{~min}$ and in a $0.01 \mathrm{M}$ sodium carbonate for 30 min. The extracted SF was washed with distilled water. After drying at $60^{\circ} \mathrm{C}$, SF $(20 \% \mathrm{w} / \mathrm{v})$ was dissolved in $9.3 \mathrm{M}$ $\mathrm{LiBr}$ solution at $70^{\circ} \mathrm{C}$ for $1 \mathrm{~h}$. This solution was dialysed for 
3 days. The SF membranes were obtained by casting the solution in 24-well culture plates (BD Biosciences) and slow dried at room temperature. In order to induce $\beta$-sheet conformation the membranes were immersed in methanol/water solutions with increasing concentration of methanol, up to $100 \%$ to preserve the structural integrity during the drying process. Ideally it would be preferable to produce a membrane through self-assembly processes as a way to recreate the natural process of SF fiber formation and mimic the natural silk structure. However, these processes remain poorly understood which makes the reconstitution of silk solutions into materials with properties comparable to the native state problematic. $^{52}$ Therefore, we decided to induce beta-sheet through methanol treatment in order to achieve reproducible surfaces that could be comparable to those found in the native SF fibers.

\section{Mechanical properties}

The mechanical properties of the produced SF textile constructs were determined by performing quasi-static tensile tests (Instron 4505 Universal Machine). The tensile modulus, ultimate tensile strength and strain at maximum load were measured using a load cell of $1 \mathrm{kN}$ at crosshead speed $5 \mathrm{~mm} / \mathrm{min}$. The tensile modulus was determined in the most linear region of the stress/strain curve using the secant method. Both dry and hydrated samples were tested. The tests with dry samples were conducted at $25^{\circ} \mathrm{C}$ and $50 \%$ of humidity. Hydrated samples were prepared by immersion in a phosphate-buffer saline solution (PBS) at $\mathrm{pH}$ of 7.4 for 3 days. Five samples with dimensions of $15 \times$ $40 \mathrm{~mm}^{2}$ were analyzed per condition.

\section{Surface treatments}

Etching with $\mathrm{NaOH}$. SF structures were immersed in $0.5 \mathrm{M}$ $\mathrm{NaOH}$ solution for $60 \mathrm{~min}$ at $30^{\circ} \mathrm{C}$.

$\boldsymbol{U V} / \mathrm{O}_{3}$ treatment. The $\mathrm{UV} / \mathrm{O}_{3}$ treatment was performed in a commercial $\mathrm{UV} / \mathrm{O}_{3}$ chamber (Jelight Company, Model 42) using a standard fused quartz lamp that emits a continuous radiation of $254 \mathrm{~nm}$ with an intensity of $28 \mathrm{~mW} / \mathrm{cm}^{2}$. Samples were placed on glass slides and subsequently inserted into the $\mathrm{UV} / \mathrm{O}_{3}$ chamber at a distance of about $5 \mathrm{~mm}$ from the UV source. The $\mathrm{O}_{3}$ gas employed during irradiation had a purity of $99.995 \%$ (Linde, H. Ollriegelskreuth, Germany) and a total pressure of 5 mbar. After exposure samples were washed with distilled water for $48 \mathrm{~h}$ at $50^{\circ} \mathrm{C}$ and dried for $10 \mathrm{~min}$ at $37^{\circ} \mathrm{C}$.

Plasma grafting. The most attractive aspect of plasmabased surface treatments is that several gases can be employed to produce plasma and thus activate the surface functionality of structures, without requiring high chemical consumption. In this study, plasma treatment was performed using a radio frequency $(13.56 \mathrm{MHz})$ plasma reactor (PlasmaPrep5, Gala Instruments, Germany). Samples were exposed to $\mathrm{O}_{2}$ plasma at $30 \mathrm{~W}$ of power for $15 \mathrm{~min}$. During the treatment, the gas flow was adjusted in order to keep a constant pressure of $20 \mathrm{~Pa}$ inside the reactor. Immediately after plasma treatment, the activated surfaces were immersed in three different solutions 5\% (v/v) AAc, $100 \mathrm{mM} \mathrm{VPA} / 2$-propanol and 10\% (v/v) VSA for $2 \mathrm{~h}$ at RT, in order to induce carboxylic, sulfonic or phosphonic groups' formation. Solutions were previously degassed by nitrogen $\left(\mathrm{N}_{2}\right)$ bubbling to avoid the reaction between the induced functional groups and the $\mathrm{O}_{2}$ present in the solutions. After each reaction, samples were washed with distilled water and then dehydrated by immersion in absolute ethanol followed by over drying at $37^{\circ} \mathrm{C}$ for $24 \mathrm{~h}$.

\section{Scanning electron microscopy}

The surface morphology of the produced SF textile constructs was analyzed before and after the different surface treatments using a Leica Cambridge S-360 (United Kingdom) Scanning Electron Microscope.

After cultures, cell morphology and distribution on the surface of the 2D membranes and 3D textile scaffolds were also analyzed by scanning electron microscopy (SEM). After each predefined time point, the cell-seeded structures were washed with Phosphate Buffered Saline (PBS; Sigma) and fixed with $2.5 \%$ glutaraldehyde (Sigma) solution in PBS. Samples were again rinsed with PBS and dehydrated using a series of ethanol solutions (30\%, 50\%, 60\%, 70\%, 80\%, $90 \%$, and $100 \%, v / v)$. Finally, the samples were treated with hexamethylidisilazane (HMDS; Electron Microscopy Sciences) and air dried overnight at RT. Prior observation all samples were sputter-coated with gold (Fisons Instruments, Sputter Coater SC502, United Kingdom) and the micrographs were taken at an accelerating voltage of $15 \mathrm{kV}$ at different magnifications.

\section{Atomic force microscopy}

The surface roughness of the samples was determined by AFM. The analysis was performed for three regions per sample $\left(5 \times 5 \mu^{2}\right)$ using tapping mode (Veeco) connected to a NanoScope III (Veeco) with noncontacting silicon nanoprobes (ca. $300 \mathrm{kHz}$, set point 2-3 V) from Nanosensors (Switzerland). All images were fitted to a plan using the 3rd degrees flatten procedure included in the NanoScope software version 4.43r8. The surface roughness was calculated as Ra (mean absolute distance from mean flat surface). The values are presented as mean \pm standard deviation.

\section{Contact angle and surface energy}

Understanding the surface behavior of a biomaterial in contact with hydrated media is of great importance to predict its interactions with cells, when applied in a particular biomedical application. The wettability of untreated and surface modified silk fibroin was assessed by contact angle $(\theta)$ measurements. Unfortunately, the morphology (porous irregular surface creating a capillary effect) of the present samples/textiles did not allow direct determination of the contact angle with enough precision. In fact, there are not many characterization techniques with enough sensitivity to allow surface analysis of such samples with complex shape. Therefore, "models" have been prepared in the form of membranes, trying to recapitulate some of the surface 
properties of the textiles. The contact angle depends on several parameters such as surface chemistry, roughness and crystallinity among others that can't be controlled separately. While the roughness of the membranes and the textiles is obviously different, the crystallinity and surface chemistry can be reproduced using the same procedure. Because of these differences between membranes and textiles the discussion will not be solely based on the contact angle measurements; the results are complemented with the other characterization techniques presented in this study.

Static contact angle measurements of the untreated and surface modified SF membranes were obtained by the sessile drop method using a contact angle meter OCA15 + with a high performance image processing system (DataPhysics Instruments, Germany). Two different liquids were used: ultrapure water $\left(\mathrm{upH}_{2} \mathrm{O}\right)$ and diiodomethane $\left(\mathrm{CH}_{2} \mathrm{I}_{2} ; 1 \mu \mathrm{L}\right.$, HPLC grade), added by a motor-driven syringe at room temperature. Two samples of each material were used and five measurements were carried out for each sample. The surface free energy $(\gamma)$ of the treated and untreated samples was calculated using the Owens, Wendt, Rabel, and Kaelble (OWRK) equation. ${ }^{53,54}$

\section{X-ray photoelectron spectroscopy}

X-ray photoelectron spectroscopy (XPS) analysis was performed to characterize the surface elemental composition of the modified and unmodified samples using a Thermo Scientific K-Alpha ESCA instrument. Monochromatic $\mathrm{Al}-\mathrm{K} \alpha$ radiation $(\mathrm{h} v=1486.6 \mathrm{eV})$ was used to perform the XPS measurements and the photoelectrons were collected from a take-off angle of $90^{\circ}$ relative to the samples surface. The spectrometer was operated in a constant analyser energy (CAE) mode with $100 \mathrm{eV}$ pass energy for the survey spectra and $20 \mathrm{eV}$ pass energy for the high-resolution spectra. Charge referencing was adjusted by setting the lower binding energy of $\mathrm{C} 1 \mathrm{~s}$ peak at $285.0 \mathrm{eV}$. Overlapping peaks were resolved into their individual components by using the XPSPEAK 4.1 software.

\section{Cell culture}

A mouse fibroblast cell line (L929), acquired from the European Collection of Cell Cultures (ECACC, United Kingdom), was used to assess the eventual cytotoxicity of the developed scaffolds. For that purpose, the 3D textile materials were cut into $16 \mathrm{~mm}$ diameter discs, and immobilized into the bottom of 24-well culture plates (BD Biosciences) using CellCrown ${ }^{\circledR}$ inserts (Scaffdex, Finland). Cells were grown as monolayer cultures in Dulbecco's Modified Eagle's Medium (DMEM; Sigma Aldrich; Germany) supplemented with 10\% fetal bovine serum (FBS; Biochrom, Germany) and 1\% antibiotic-antimycoticsolution (Gibco, United Kingdom). At confluence cells were detached from the culture flasks using trypsin (Sigma), centrifuged, resuspended in the cell-culture medium, and seeded in the scaffolds at a density of $3 \times 10^{4}$ cells/sample. The cell-seeded scaffolds were incubated at $37^{\circ} \mathrm{C}, 5 \% \mathrm{CO}_{2}$ and $95 \%$ humidity, for 1,5 , and $24 \mathrm{~h}$. Tissue culture polystyrene (TCPS; Sarstedt) coverslips and SF membranes were used as control surfaces.

\section{DNA quantification assay}

The L929 cell proliferation onto the developed 3D textile constructs was assessed by using a fluorimetric doublestrand DNA quantification kit (PicoGreen, Molecular Probes, Invitrogen Corporation) following manufacturer's instructions. After each time point, scaffolds were rinsed with PBS and transferred into $1.5 \mathrm{~mL}$ microtubes, containing $1 \mathrm{~mL}$ of ultrapure water, to induce an osmotic shock. An additional thermal shock was provoked by placing the scaffolds at $37^{\circ} \mathrm{C}$ for $1 \mathrm{~h}$ prior to $-80^{\circ} \mathrm{C}$ freezing. Prior to dsDNA quantification, samples were thawed and sonicated for $1 \mathrm{~h}$. A PicoGreen solution was mixed with the samples and the standards (ranging from 0 to $2 \mathrm{mg} / \mathrm{mL}$ ) in a 200:1 ratio and placed into opaque 96-well plates. Each sample or standard was made in triplicate. After 10 min of incubation in the dark, the fluorescence was read into a microplate enzyme-linked immunosorbent assay reader (BioTek) at $485 / 528 \mathrm{~nm}$ of excitation/emission. To exclude the materials auto fluorescence, the same quantification assay was performed for samples without cells but subjected to the same culture conditions.

\section{Statistical analysis}

All the numerical results are presented as mean \pm standard deviation. Statistical tests were performed with GraphPad Prism 5.0 (GraphPad Software). A one-way analysis of variance (ANOVA) was used to evaluate the AFM and contact angle results, using the Tukey's method as a post hoc pairwise comparison test. Statistical significance of DNA quantification, obtained from three independent experiments, and tensile tests results were determined with a two-way ANOVA test followed by Bonferroni's as multiple comparasion analysis method. The significance level was ${ }^{*} p<0.05$, ${ }^{* *} p<0.01$, and ${ }^{* * *} p<0.001$.

\section{RESULTS AND DISCUSSION}

When developing biomaterials to be used in tissue engineering that intend to direct cellular behavior, the ability to tailor their surface properties becomes an issue of great importance. Slight changes in the surface topography and chemistry can be responsible for significant changes on cell behavior.

\section{Mechanical properties}

SF fibers are known for their extraordinary mechanical properties that rival most of the high performance synthetic fibers. This behavior results from their unique molecular structure and protein conformation. ${ }^{55}$ In a previous study ${ }^{30}$ the mechanical properties of the produced knitted SF matrices were measured in the longitudinal and transversal direction confirming their anisotropic character. Anisotropy is particularly interesting when considering that most tissues present a high degree of anisotropy. Herein, the mechanical properties of the untreated and surface modified SF textile constructs were investigated by performing quasistatic tensile tests in the longitudinal direction, as presented in Figure 1. 
a

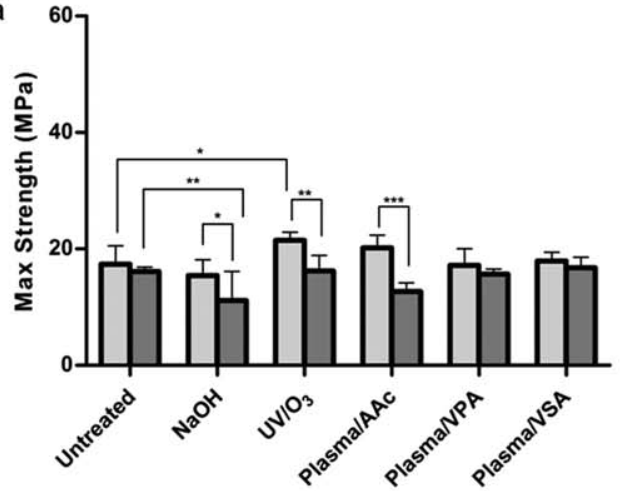

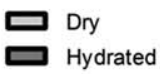

Hydrated
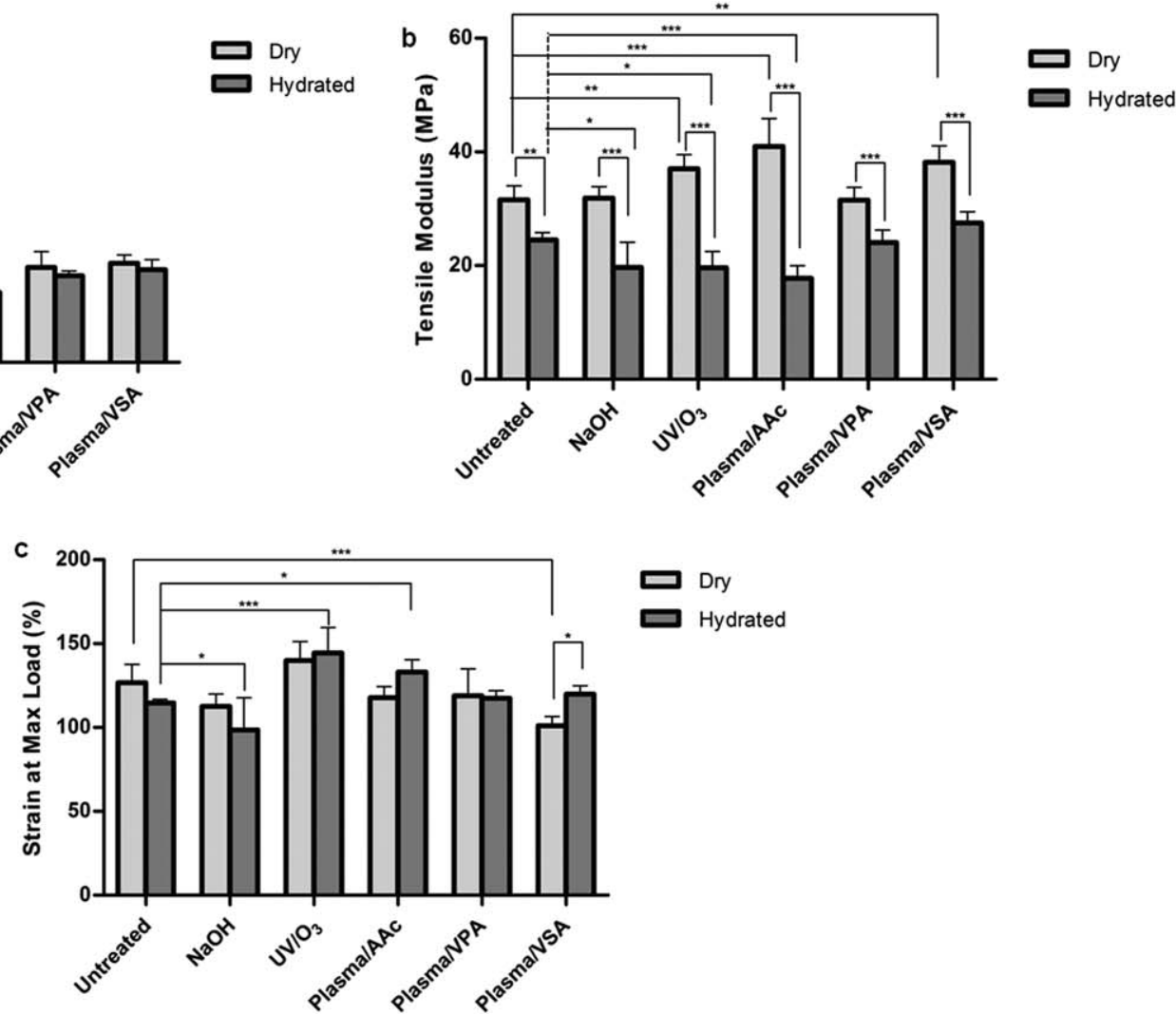

FIGURE 1. Effect of the different surface modifications on (a) maximum strength (MPa), (b) E-modulus (MPa), and (c) strain at maximum load (\%) obtained for SF textile matrices at dry $\left(25^{\circ} \mathrm{C}\right)$ and hydrated state (isotonic phosphate-buffer saline solution; $37{ }^{\circ} \mathrm{C}$ ), in the longitudinal direction $\left({ }^{*} p<0.05 ;{ }^{* *} p<0.01\right.$, and ${ }^{* * *} p<0.001$ ).

As expected, when comparing the untreated and the surface-treated textile constructs in the dry state no relevant changes were detected in terms of maximum strength and elongation at break. Even though, when considering the modulus, a slight increase was observed for $\mathrm{UV} / \mathrm{O}_{3}$, plasma/ AAc and plasma/VSA, indicating that these structures have become stiffer.

By analysing the mechanical properties of the untreated SF textiles in the dry and hydrated states it was possible to see that while the changes on the maximum strength and elongation at break were not significant, a significant decrease $(p<0.01)$ in the tensile modulus was observed in the presence of PBS solution. Considering the properties of the treated textile matrices, a significantly lower maximum strength was observed for hydrated samples treated with $\mathrm{NaOH}(p<0.05), \mathrm{UV} / \mathrm{O}_{3}(p<0.01)$, and plasma/AAc $(p<0.001)$. The hydration process induced an even higher difference for the modulus, indicating that all the surface treatments had impacted the mechanical performance in the wet state. In opposition, strain at break was significantly higher $(p<0.05)$ for the plasma/VSAtreated hydrated samples in comparison to the dried ones. No significant differences were observed between the hydrated and dried samples treated with the remaining treatments. A decrease in the modulus was observed for the hydrated samples treated with $\mathrm{NaOH}, \mathrm{UV} / \mathrm{O}_{3}$, and plasma/AAc as compared with the untreated samples while an increase in the maximum strain at break was observed for the samples treated with $\mathrm{UV} / \mathrm{O}_{3}$ and plasma/ AAc. The differences in mechanical properties of the SF textile constructs when these are in the hydrated state are related with the effect of water molecules incorporating the structure of the fibers, as reported by Perez-Rigueiro et al. $^{56} \beta$-sheet platelets in SF constitute around $50-60 \%$ of the total volume of the fiber. ${ }^{51}$ It is accepted that this crystalline domain is not affected by water molecules. Thus, the observed changes between the elastic modulus of samples tested in air and in the buffered solution can be attributed to alterations in the amorphous regions. Immersion in water disrupts the hydrogen bonds between chain segments in the amorphous phase, leaving van der Waals bonds to dominate, thus reducing the initial modulus. In this sense, it is expected that the surface treatments in wet conditions might attack preferentially the amorphous phase, corresponding to a general increase in the ductility with more impact in case of the scaffolds treated with plasma/AAc and $\mathrm{UV} / \mathrm{O}_{3}$ treatments, as observed by the general decrease in the modulus from the dry to the wet state. In case of $\mathrm{UV} / \mathrm{O}_{3}$ it is known that SF has a high permeability to oxygen, ${ }^{57}$ which has favored the modification of the fibers beyond the surface. In general, it is possible to affirm that the impact of the treatments in the final mechanical performance of the textile constructs was not severe. 


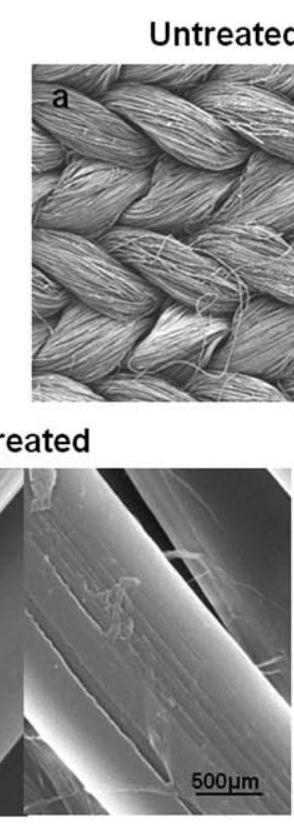

PlasmalAAc

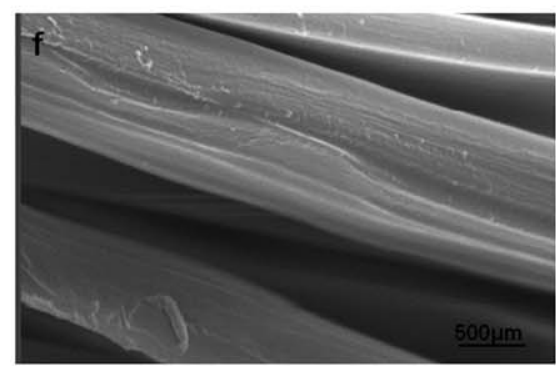

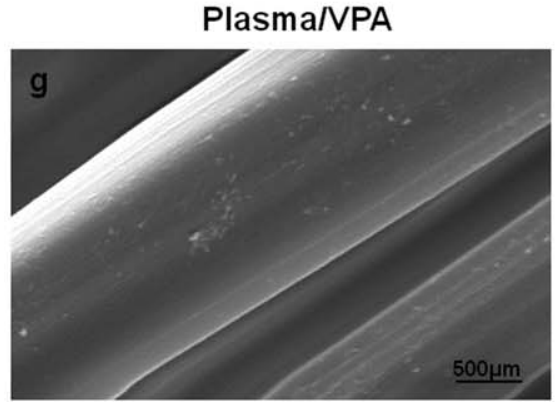

Untreated (side B)

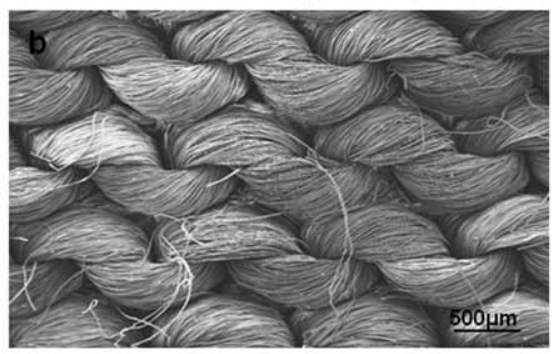

$\mathrm{NaOH}$
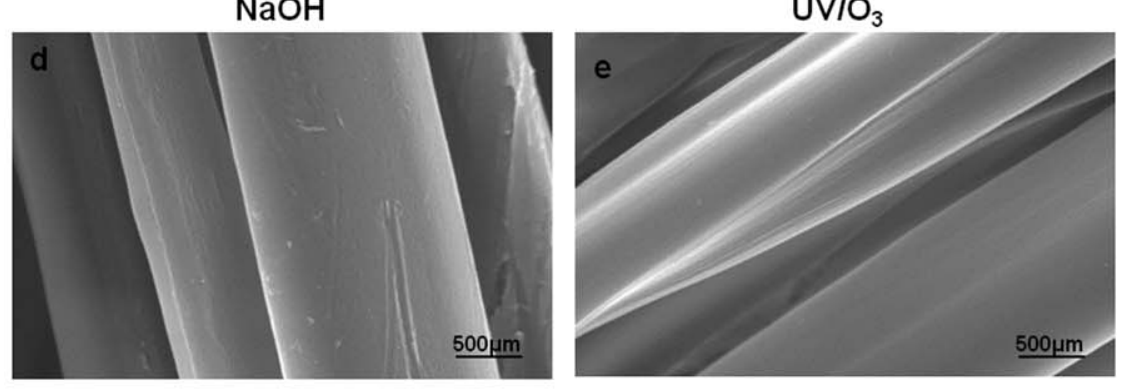

Plasma /VSA

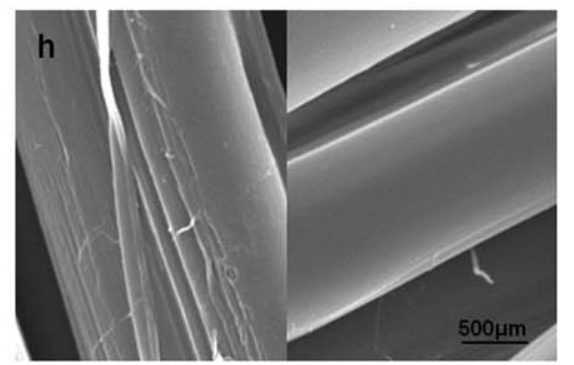

FIGURE 2. Scanning electron micrographs of (a) side A and (b) side B of the SF knitted structure and magnifications of the fibers on the top side (c) before and $(\mathrm{d}-\mathrm{h})$ after the different surface treatments.

\section{Surface morphology and topography}

The morphology of the surface of the scaffolds as well as of the surface of the fibers that form the 3D structure were analyzed by SEM. Figure 2 presents the scanning electron micrographs of side A and B of the SF knitted structure and magnifications of the fibers before and after the surface treatments.

Scanning electron micrographs of the untreated SF fibers revealed in general a smooth surface without pores or defects [Figure 2(c)]. The SEM analysis of the treated fibers reveals some surface irregularities especially in the case of plasma/AAc and plasma/VSA treatments [Figure 2(f,h)]. Nevertheless, it is difficult by using only SEM analysis to clearly differentiate the surface treatments based on the fiber morphology. In some cases it was possible to observe areas with fibers exhibiting smooth surfaces and others with fibers presenting more irregular surfaces in the same sample, as for instances in case of untreated samples and after treatment with plasma/VSA [Figure 2(c,h)]. It is important to state that degumming process can cause per se some physical changes in the fibers [Figure 2(c)].

The characterization of the surface of the SF fibers and the influence of the several surface modifications was done indirectly, through the analysis of SF membranes. Although it was clear that the starting surface of the membranes casted from regenerated SF can be different from the surface fibers in terms of crystalinity, it is plausible to correlate the effect of the proposed treatments in both scenarios.

Figure 3 presents the AFM images of the membrane surfaces before and after different surface treatments. The correspondent average roughness for each surface is presented in Figure 4.

The wet chemical treatment with $\mathrm{NaOH}$ resulted in a smoother surface as compared to the untreated sample. In contrast, the $\mathrm{UV} / \mathrm{O}_{3}$ treatment significantly increased the roughness of the surface. Regarding the modifications following plasma preactivation only the treatment with acrylic acid was able to considerably smooth the surface. Nevertheless, etching processes are unavoidable when polymers are exposed to plasma. In general, the surface nanotopography and the average roughness were affected by the applied treatments. It is well recognized that small changes in the surface topography can affect cell behavior. ${ }^{58}$ However, it is not possible to dissociate this physical modification from those occurring in due to changes in the wettability and chemical composition. 
a. Untreated

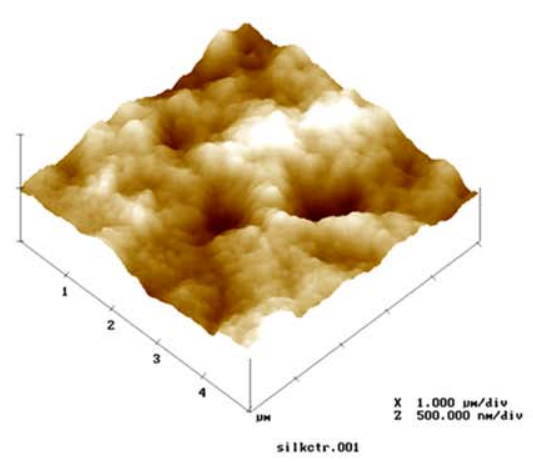

d. PlasmalAAc

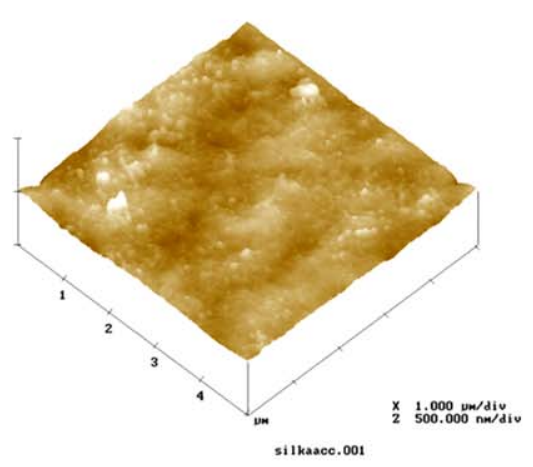

b. $\mathrm{NaOH}$

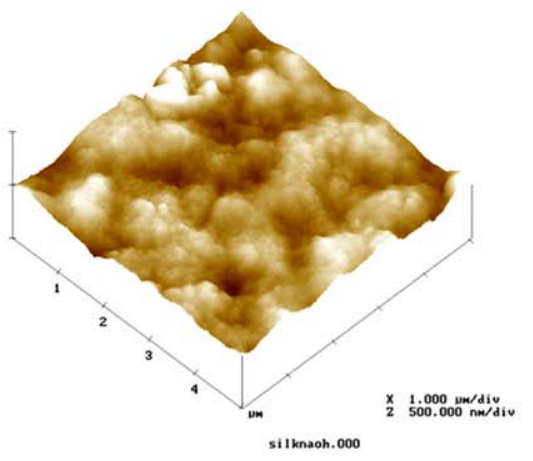

e. Plasma/VPA

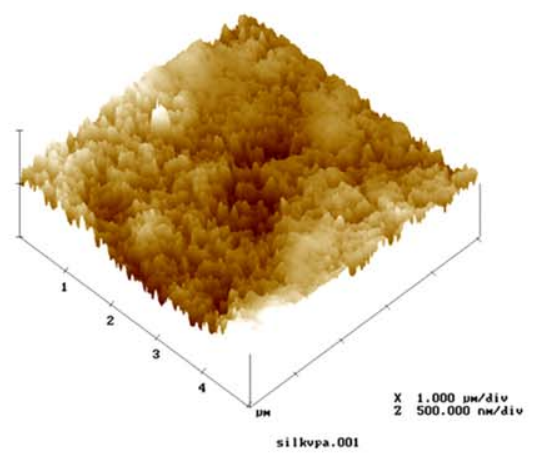

c. $\mathrm{UVIO}$

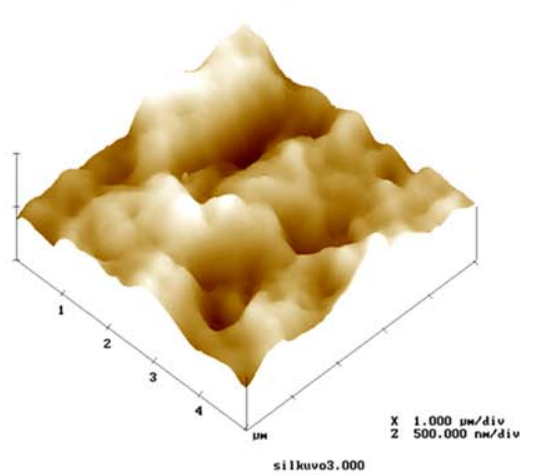

f. Plasma/VSA

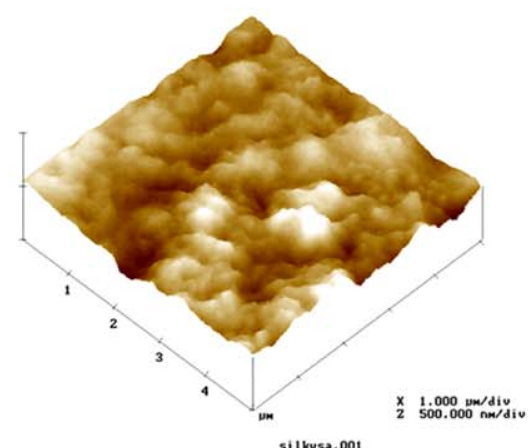

FIGURE 3. AFM images of the SF surfaces (a) before and (b-f) after the different surface treatments. [Color figure can be viewed in the online issue, which is available at wileyonlinelibrary.com.]

\section{Surface wettability and composition}

The contribution of the dispersion and polar interactions to the surface energy was calculated by considering that the intermolecular attraction, which causes surface energy, results from a variety of intermolecular forces. Most of these forces are function of the specific chemical nature of a particular material, and the surface energy can be compiled as $\gamma_{\mathrm{p}}$ (polar interactions), taking into consideration that the

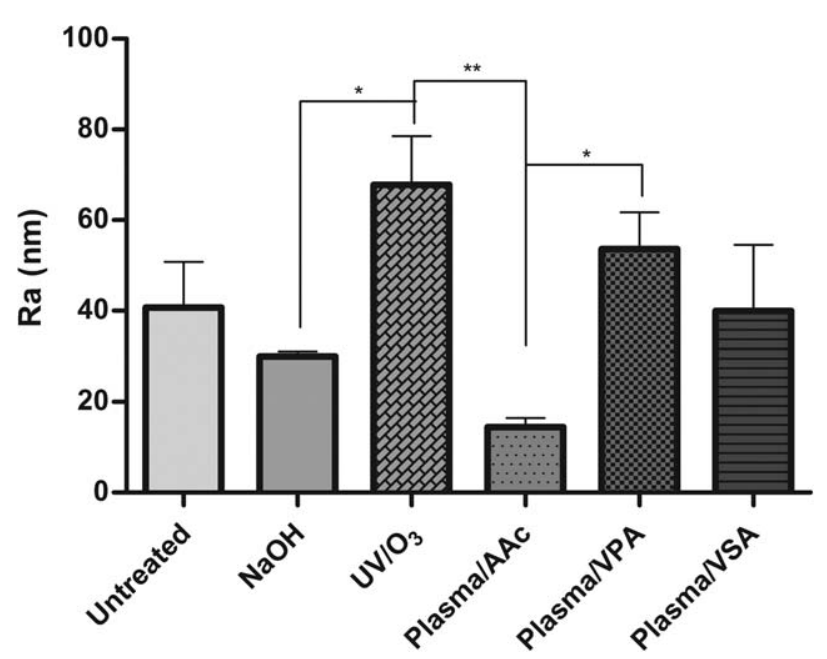

FIGURE 4. Average roughness $\left(R_{\mathrm{a}}\right)$ of the SF surfaces before and after the different surface treatments $\left({ }^{*} p<0.05 ;{ }^{*} p<0.01\right)$. dispersion forces $\left(\gamma_{\mathrm{d}}\right)$ are always present in all systems, independently of their chemical nature. The water contact angle values obtained for the untreated and surface-treated SF membranes are plotted in Figure 5 and the respective calculated surface energies are presented in Table I.

In Figure 5, it is possible to observe a general trend toward an increase in the hydrophobicity of the treated

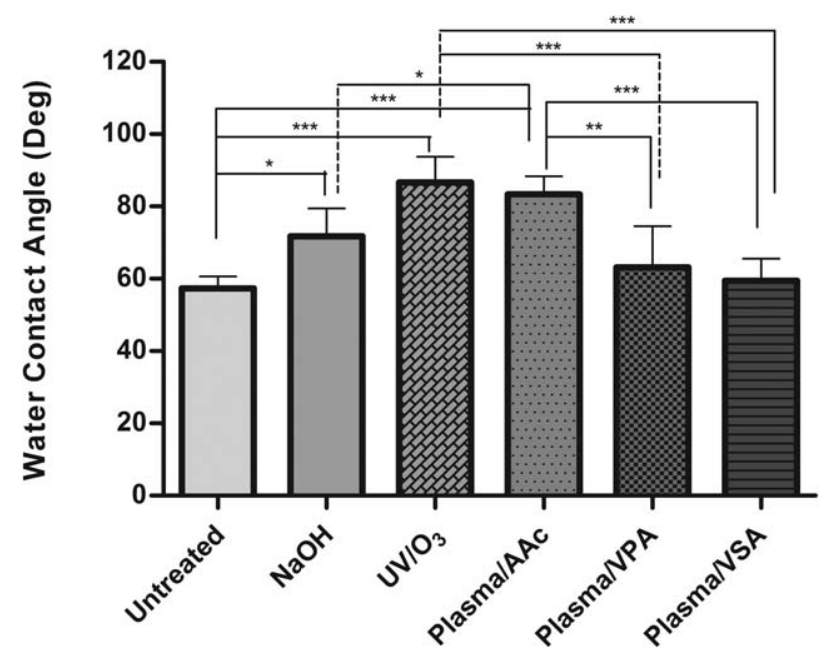

FIGURE 5. Water contact angles obtained for the untreated and treated SF surfaces. The significance level is ${ }^{*} p<0.05,{ }^{* *} p<0.01$, and $* * * p<0.001$. 
TABLE I. Contact Angle Values ( $\theta)$ Measured for the Untreated and Treated Surfaces and Respective Calculated Surface Energies $\left(\gamma_{s}\right)$

\begin{tabular}{lccccc}
\hline & \multicolumn{2}{c}{ Contact Angle $(\theta)$} & & & \\
\cline { 2 - 3 } Treatment & \multicolumn{1}{c}{$\mathrm{H}_{2} \mathrm{O}$} & $\mathrm{CH}_{2} \mathrm{I}_{2}$ & & Surface Energy, $\gamma_{\mathrm{s}}\left(\gamma_{\mathrm{s}}{ }^{\mathrm{d}}+\gamma_{\mathrm{s}}{ }^{\mathrm{p}}\right)(\mathrm{mN} / \mathrm{m})$ & $\mathrm{Ratio}, \gamma_{\mathrm{s}}{ }^{\mathrm{d}} / \gamma_{\mathrm{s}}{ }^{\mathrm{p}}$ \\
\hline Untreated & $57.34 \pm 3.27$ & $46.22 \pm 5.95$ & & $45.31(25.66+19.66) \pm 0.04$ & 1.30 \\
$\mathrm{NaOH}$ & $71.78 \pm 7.70$ & $56.56 \pm 8.62$ & & $35.36(20.44+14.92) \pm 0.06$ & 1.37 \\
$\mathrm{UV} / \mathrm{O}_{3}$ & $86.62 \pm 7.14$ & $48.5 \pm 4.99$ & $32.39(27.61+3.82) \pm 0.02$ & 7.22 \\
$\mathrm{Plasma/AAc}$ & $83.34 \pm 5.04$ & $55.28 \pm 9.52$ & $30.02(24.36+5.72) \pm 0.02$ & 1.26 \\
Plasma/VPA & $63.18 \pm 11.36$ & $58.76 \pm 10.14$ & & $40.33(24.00+16.33) \pm 0.07$ & 1.47 \\
Plasma/VSA & $59.48 \pm 6.09$ & $42.44 \pm 7.91$ & $45.92(26.90+19.02) \pm 0.07$ & 1.41 \\
\hline
\end{tabular}

surfaces with significantly different values for $\mathrm{NaOH}$ etching, $\mathrm{UV} / \mathrm{O}_{3}$ and plasma/AAc treatments. Consequently, a decrease in the surface energy was registered due to a general decrease in the polar component most significant for $\mathrm{UV} / \mathrm{O}_{3}$ and plasma/AAc treatments (Table I). In the case of $\mathrm{NaOH}$ treatment, the decrease in surface energy was also due to a decrease in the dispersive component. Generally, all treatments can result in simultaneous etching and modification that is expected to mainly affect the amorphous phase in SF. SF crystalline phase ( $\beta$-sheet) represents near half of the total composition while the remaining amorphous phase is majorly composed of random coil, $\alpha$-helix and turn secondary structures. ${ }^{51}$ An increase in the surface crystallinity as a result of conformational change in the amorphous domains to silk II and/or the exposure of the crystalline phase due to an etching effect might be also contributing to an increase in the surface hydrophobicity. Further studies need to be conducted in order to confirm this possibility.

The surface composition and atomic ratios of the untreated and treated samples, investigated by XPS, are presented in Table II. The wet chemical treatment with $\mathrm{NaOH}$ resulted in etching as confirmed by the surface analysis. XPS results showed lower oxygen content on the $\mathrm{NaOH}$ treated surface (Table II). The obtained result might be associated to the higher sensitivity of the oxygen containing moieties (related with the amorphous domains) to degradation/hydrolysis processes, that is, the scission of the chains that occur predominantly at the places where those functionalities are. As expected, the lower oxygen content was associated with higher water contact angle value (less hydrophilic surface, Figure 4, Table I) and smoother surface after the treatment.

TABLE II. Surface Composition and Atomic Ratios of Modified and Nonmodified SF Samples Determined by XPS

\begin{tabular}{lcccccc}
\hline Modification & $\mathrm{O}$ & $\mathrm{N}$ & $\mathrm{C}$ & $\mathrm{S}$ & $\mathrm{P}$ & $\mathrm{O} / \mathrm{C}$ \\
\hline Untreated & 19.6 & 14.9 & 63.5 & - & - & 0.31 \\
$\mathrm{NaOH}$ & 15.3 & 11.9 & 72.6 & - & - & 0.21 \\
$\mathrm{UV} / \mathrm{O}_{3}$ & 25.1 & 11.9 & 59.0 & - & - & 0.43 \\
$\mathrm{Plasma} / \mathrm{AAc}$ & 21.3 & 15.2 & 61.5 & - & - & 0.35 \\
Plasma/VPA & 28.4 & 11.0 & 49.8 & - & 2.7 & 0.57 \\
Plasma/VSA & 19.6 & 6.1 & 73.2 & 0.1 & - & 0.27 \\
\hline
\end{tabular}

The modification with $\mathrm{UV} / \mathrm{O}_{3}$ resulted in higher oxygen content in the XPS spectrum of the modified material (Table II). This result is in agreement with previous reports for different polymers treated by $\mathrm{UV} / \mathrm{O}_{3}$ and with the expected ongoing oxidation induced by the ozone presence. ${ }^{59-61}$ Surprisingly, the water contact angle for the treated samples was significantly higher when compared to the untreated samples. The significant increase in roughness (Figure 4) resulting from the surface etching can be a possible explanation for the obtained results, most probably due the Cassie-Baxter effect. ${ }^{62}$

AAc grafted surfaces presented a slight increase in the oxygen to carbon rate content (Table II), together with a significant smoothening of the surface [Figures 3(d) and 4]. This smoothening may indicate that upon grafting, acrylic acid monomers started to fill the valleys similarly to the phenomenon recently reported by Gupta et al. ${ }^{63}$ for the grafting of AAc onto plasma-treated polycaprolactone monofilament surface. It is known that the etching by plasma treatment can contribute per se to an increase in the hydrophobicity of silk surfaces, ${ }^{64}$ while the subsequent grafting with acrylic acid monomers is expected to functionalize the surface and increase its wettability. Thus, the measured significant increase in the hydrophobicity was unexpected. It is difficult to confirm the AAc grafting by XPS because all functionalities characteristic for acrylic acid (CHCOO-, COO-) are already present in the silk structure. However, the $\mathrm{C}_{1 \mathrm{~s}}$ high resolution spectra for plasma/AAc-treated surfaces is quite different from the untreated ones, showing less intensive peaks for - $\mathrm{CO}$ and -COO (Supporting Information Figure S1). This result seems to confirm that most probably etching and not grafting is preferentially occurring on the surface during plasma/AAc treatment. In case of VPA and VSAtreated samples $\mathrm{P}$ and $\mathrm{S}$, respectively, were detected in their surfaces by XPS (Supporting Information Figure S2), confirming the successful grafting although with different effectiveness. López-Pérez et al. ${ }^{65}$ have reported higher grafting efficiency for VPA-grafted surfaces that has resulted in higher number of adherent cells (SaOs-2) and higher proliferation rate. Here, it was not observed a significant change on the surface wettability leading to the assumption that the grafting yield was lower than expected. The equilibrium degree of grafting is dependent on monomer concentration, reaction temperature and the concentration of active regions created upon plasma exposure, thus further optimization of 
$1 \mathrm{~h}$
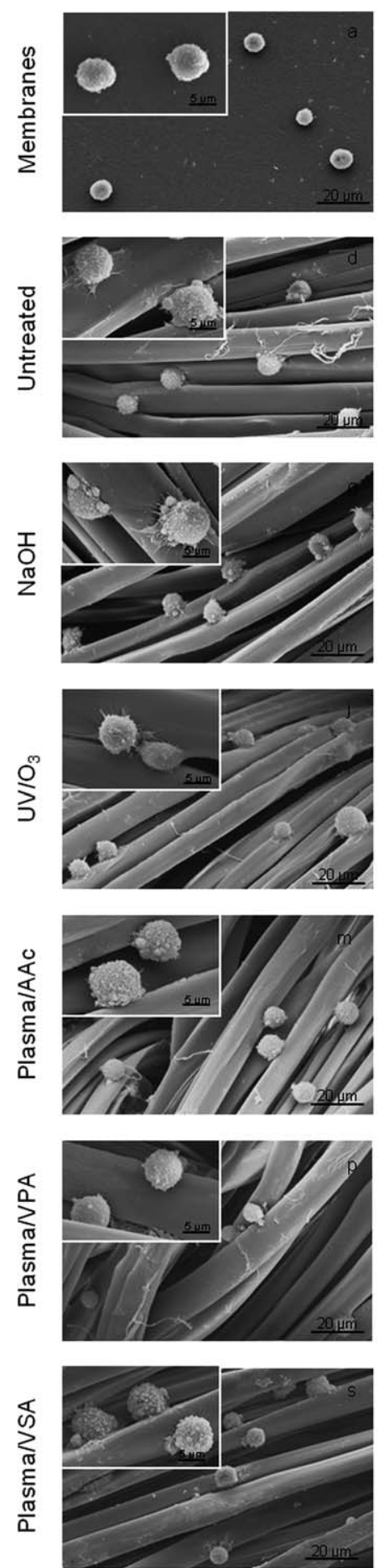

$5 \mathrm{~h}$
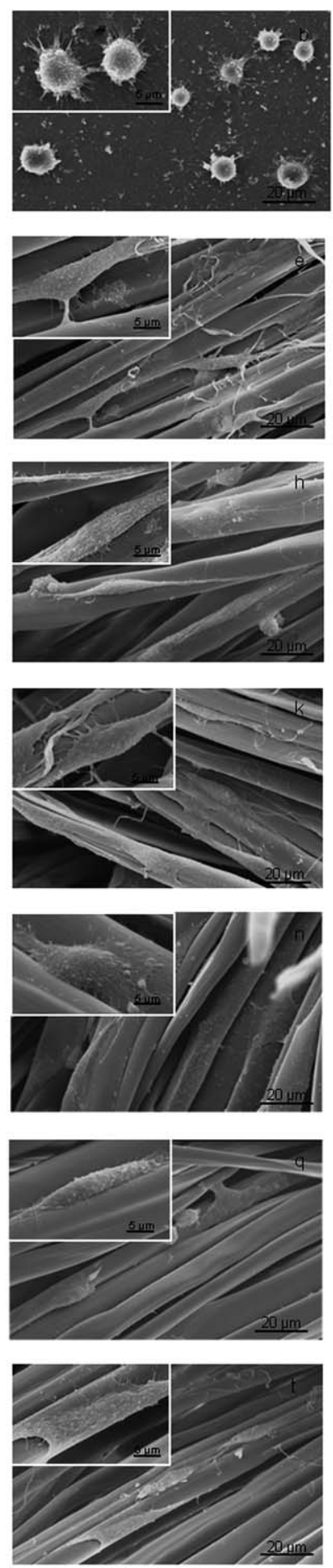

$24 \mathrm{~h}$
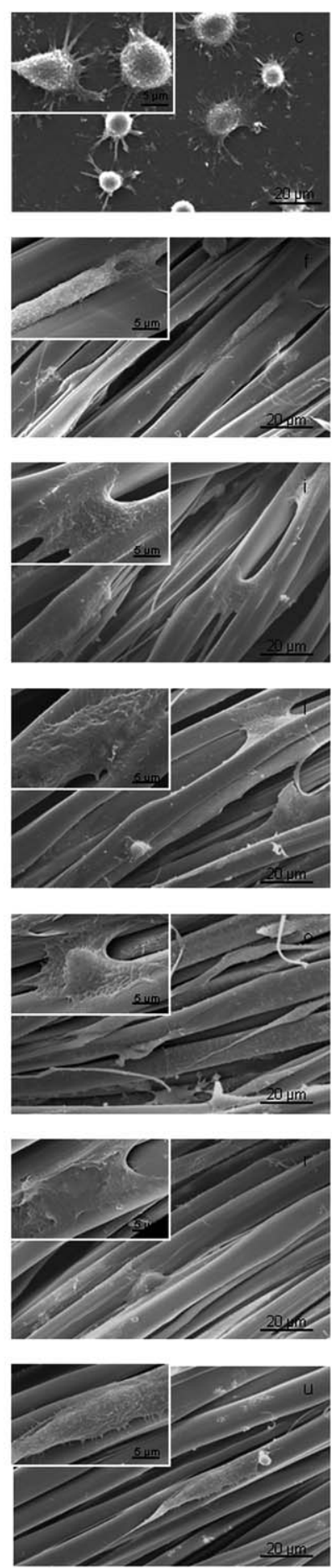

FIGURE 6. Scanning electron micrographs showing the L929 cell morphology and adhesion at the surface of (a-c) 2D silk membranes, 3D silk textile scaffolds (d-f) untreated and after the different surface modifications: (g-i) NaOH; (j-I) UV/O ${ }_{3} ;(m-0)$ plasma/AAc; (p-r) plasma/VPA; (s-u) plasma/VSA, for (a, d, g, j, m, p, and s) $1 \mathrm{~h},(\mathrm{~b}, \mathrm{e}, \mathrm{h}, \mathrm{k}, \mathrm{n}, \mathrm{q}$, and t) $5 \mathrm{~h}$, and $(\mathrm{c}, \mathrm{f}, \mathrm{i}, \mathrm{l}, \mathrm{o}, \mathrm{r}$, and $\mathrm{u}) 24 \mathrm{~h}$ of culture.

these parameters are necessary for increasing the grafting yield in this particular reaction.

\section{Cell morphology}

The effect of the applied surface treatments over initial cell adhesion was analyzed based on the morphology of L929 cells observed by SEM (Figure 6). After $1 \mathrm{~h}$ of cell culture, extensive cell colonization can be observed for the studied materials. However, the majority of the attached cells were not spread [Figure $6(a, d, g, j, m, p, s)]$. After $5 \mathrm{~h}$ of culture, cells presented typical spindle-like fibroblast morphology, showing a higher degree of spreading with some extended 
lamellipodia over the surface of all modified materials [Figure $6(\mathrm{~h}, \mathrm{k}, \mathrm{n}, \mathrm{q}, \mathrm{t})]$. This effect was even more notorious after $24 \mathrm{~h}$ of culture [Figure $6(\mathrm{i}, \mathrm{l}, \mathrm{o}, \mathrm{r}, \mathrm{u})]$. The adhered cells presented an elongated morphology and a high degree of spreading over the modified surfaces was observed, interacting and integrating well with the fibers. In agreement with these findings, Park et al. ${ }^{66}$ have reported that surfaces of poly(glycolic acid), poly(L-lactic acid), and poly(lactic-coglycolic acid) chemically modified using air plasma treatment followed by acrylic acid grafting, improved fibroblastlike cells spreading over the nanofibrous surfaces, suggesting that the carboxylic functional groups could be successfully immobilized at the scaffolds' surface improving cell attachment and proliferation in vitro. A different study using human bone marrow-derived mesenchymal stem cells (hMSCs) showed a similar cell behavior after 5 days of culture on SF films modified with sulfonic acid. ${ }^{49}$ Cells grew across the surface, exhibiting spindle-like fibroblast morphology, typical of undifferentiated hMSCs. For the untreated SF textile scaffolds, L929 cells clearly presented their typical fibroblastic morphology, attaching and stretching over the scaffolds surface [Figure 6(e,f)]. This expected cell behavior ${ }^{30}$ can be justified by the silk conformation at the scaffolds' surface as well as the presence of $-\mathrm{COOH}$ and -OH polar groups that confer a more hydrophilic character to the fibers, known to directly mediate and control cell adhesion, cell-surface interactions, cytoskeleton organization and cell shape. ${ }^{67,68}$ Cells were also able to adhere on the SF membranes [Figure $6(\mathrm{a}-\mathrm{c})$ ] showing evident lamellipodia and filopodia over the surfaces [Figure $6(b, c)]$. Nevertheless, higher cell-surface interactions were observed on the untreated fibers, which can be eventually justified by the high porosity and surface area of the fiber-based scaffolds that improve cell attachment and proliferation..$^{9-11}$

\section{Cell adhesion}

Cell adhesion rate was evaluated by quantifying the DNA content along the culture time (Figure 7). The obtained results showed that after $1 \mathrm{~h}, \mathrm{~L} 929$ cells adhered in significantly higher numbers $(p<0.001)$ to untreated scaffolds, possibly indicating a cell adaptation to the induced surface modifications. Moreover, no significant differences were identified between the scaffolds treated under different conditions. After $5 \mathrm{~h}$ of culture the number of cells adhered to the untreated structures remained the same while a significantly higher number $(p<0.001$, except for plasma/VPA: $p<0.01$ ) in comparison to $1 \mathrm{~h}$ of culture, reaching a value similar to the untreated condition, was quantified in the treated scaffolds. Nonetheless, the DNA values obtained for plasma/VPA-treated surfaces were significantly lower than those reached for structures treated by $\mathrm{NaOH}(p<0.01)$, plasma/AAc $(p<0.001)$, plasma/VSA and UV/O ${ }_{3}(p<0.05)$. After $24 \mathrm{~h}$, plasma/VPA-treated surfaces also presented significantly lower $(p<0.05)$ DNA values compared to the untreated and plasma/AAc structures. No further significant changes were observed between the untreated and treated conditions and between the treatments, revealing that the unmodified SF presents per se properties of great interest

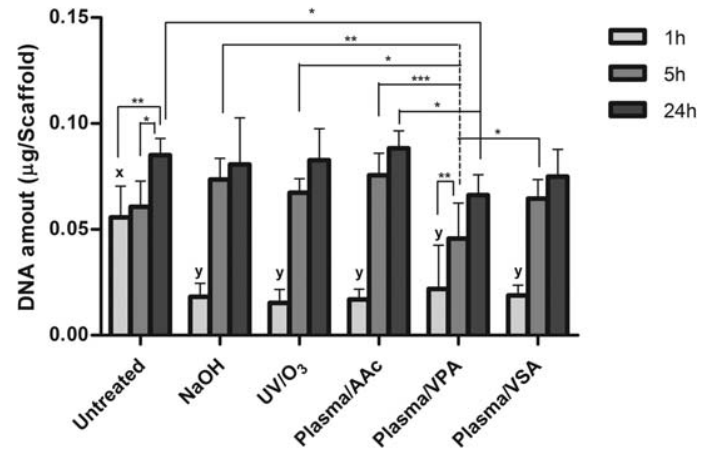

FIGURE 7. DNA amount corresponding to the number of L929 cells adhered on untreated and surface-treated 3D silk textile scaffolds after 1,5 and $24 \mathrm{~h}$ of culture. Data are shown as mean \pm standard deviation from at least $n=5 \quad\left({ }^{*} p<0.05, *^{*} p<0.01\right.$, and $\left.*^{*} p<0.001\right)$. $x$ : $p<0.001$ for all the treatments at the same culture period. $\mathrm{y}: p<0.001$ for the same treatment after 5 and $24 \mathrm{~h}$ of culture. The exceptions are represented in the graphic.

that can be used as a way to improve and facilitate cell adhesion. A different study comparing different biodegradable polymers with those chemically modified at the surface by Plasma/AAc treatment, also reported that after $24 \mathrm{~h}$ of culture, fibroblast cells adhesion rate on the surface-treated scaffolds was similar to that on control conditions. ${ }^{66}$ Moreover, the number of cells adhered to the untreated structures significantly increased after $24 \mathrm{~h}$ in comparison to $1 \mathrm{~h}$ $(p<0.01)$ and $5 \mathrm{~h}(p<0.05)$ of culture, which is not consistent with the results obtained for SF membranes whose adhesion rate did not vary after $5 \mathrm{~h}$ of culture (Data not shown).

\section{CONCLUSIONS}

SF knitted matrices were successful modified using different surface treatments, $\mathrm{NaOH}$ solution, $\mathrm{UV} / \mathrm{O}_{3}$ exposure and air plasma treatment followed by AAc, VPA and VSA grafting. The impact of the treatments on the final mechanical performance of the textile constructs was not pronounced. Nevertheless, an increase in the modulus in the dry state was significant for $\mathrm{UV} / \mathrm{O}_{3}$, plasma/AAc and plasma/VPA treatments. This was followed by an increase in the maximum strength and elongation at break. It seems that these surface treatments had a positive impact in the bulk properties of the fibers by increasing both the strength and ductility of the textile constructs. At the surface level, AFM and XPS confirmed the modification and grafting of the surfaces, although with different effectiveness, while a significant increase in the hydrophobicity was detected for $\mathrm{NaOH}$, UV/ $\mathrm{O}_{3}$ and plasma/AAc treatments. This intriguing result is presently under investigation. The in vitro preliminary biological studies showed that the number of adhered cells increases for all the studied surfaces over the culture time. However, the morphology of the adhered fibroblasts was found to be considerably different in the case of fiber-based constructs, since the cells tend to overspread both on the untreated and surface-treated fibers. This study validates the present treatments to be further investigated in a tissue engineering context, where more sensitive cells (stem cells) 
are used and can react and be stimulated by small variations in the surface environment toward neo tissue genesis and ECM formation.

\section{REFERENCES}

1. Hutmacher DW. Scaffolds in tissue engineering bone and cartilage. Biomaterials 2000;21:2529-2543.

2. Liu C, Xia Z, Czernuszka JT. Design and development of threedimensional scaffolds for tissue engineering. Chem Eng Res Des 2007;85:1051-1064.

3. Ma PX. Biomimetic materials for tissue engineering. Adv Drug Deliv Rev 2008;60:184-198.

4. Rezwan K, Chen QZ, Blaker JJ, Boccaccini AR. Biodegradable and bioactive porous polymer/inorganic composite scaffolds for bone tissue engineering. Biomaterials 2006;27:3413-3431.

5. Costa-Pinto AR, Reis RL, Neves NM. Scaffolds based bone tissue engineering: The role of chitosan. Tissue Eng Part B Rev 2011;17: 331-347.

6. Salgado AJ, Coutinho OP, Reis RL. Bone tissue engineering: State of the art and future trends. Macromol Biosci 2004;4:743-765.

7. Tuzlakoglu K, Reis RL. Biodegradable polymeric fiber structures in tissue engineering. Tissue Eng Part B Rev 2009;15:17-27.

8. Oliveira AL, Malafaya PB, Costa SA, Sousa RA, Reis RL. Microcomputed tomography (micro-CT) as a potential tool to assess the effect of dynamic coating routes on the formation of biomimetic apatite layers on 3D-plotted biodegradable polymeric scaffolds. J Mater Sci Mater Med 2007;18:211-223.

9. Gomes ME, Holtorf HL, Reis RL, Mikos AG. Influence of the porosity of starch-based fiber mesh scaffolds on the proliferation and osteogenic differentiation of bone marrow stromal cells cultured in a flow perfusion bioreactor. Tissue Eng 2006;12:801-809.

10. Chen M, Patra PK, Lovett ML, Kaplan DL, Bhowmick S. Role of electrospun fibre diameter and corresponding specific surface area (SSA) on cell attachment. J Tissue Eng Regen Med 2009;3: 269-79.

11. Gomes ME, Sikavitsas VI, Behravesh E, Reis RL, Mikos AG. Effect of flow perfusion on the osteogenic differentiation of bone marrow stromal cells cultured on starch-based three-dimensional scaffolds. J Biomed Mater Res A 2003;67:87-95.

12. Sumanasinghe R, King MW. New trends in biotextiles-the challenge of tissue engineering. J Text Apparel Technol Manage 2003;3:1-13.

13. Tao X. Smart Fibres, Fabrics and Clothing, in Textile Scaffolds in Tissue Engineering. Cambridge: Woodhead Publishing; 2001.

14. Sumanasinghe R, King MW. The applications of biotextiles in tissue engineering. J Text Apparel Technol Manage 2005;9:80-90.

15. Wang $X G$, Han $C M$, Hu XL, Sun HF, You CG, Gao CY, Yang HY. Applications of knitted mesh fabrication techniques to scaffolds for tissue engineering and regenerative medicine. J Mech Behavior Biomed Mater 2011;4:922-932.

16. Zou $X H$, Zhi $Y L$, Chen $X$, Jin $H M$, Wang $L L$, Jiang $Y Z$, Yin $Z$, Ouyang HW. Mesenchymal stem cell seeded knitted silk sling for the treatment of stress urinary incontinence. Biomaterials 2010; 31:4872-4879.

17. Yagi T, Sato M, Nakazawa $Y$, Tanaka K, Sata M, Itoh K, Takagi $Y$, Asakura T. Preparation of double-raschel knitted silk vascular grafts and evaluation of short-term function in a rat abdominal aorta. J Artif Organs 2011;14:89-99.

18. Gundy S, Manning G, O'Connell E, Ella V, Harwoko MS, Rochev $Y$, Smith T, Barron V. Human coronary artery smooth muscle cell response to a novel PLA textile/fibrin gel composite scaffold. Acta Biomater 2008;4:1734-1744.

19. Van Lieshout MI, Vaz CM, Rutten MCM, Peters GWM, Baaijens FPT. Electrospinning versus knitting: Two scaffolds for tissue engineering of the aortic valve. J Biomater Sci Polym Ed 2006; 17(1-2):77-89.

20. Sahoo S, Toh SL, Goh JCH. A bFGF-releasing silk/PLGA-based biohybrid scaffold for ligament/tendon tissue engineering using mesenchymal progenitor cells. Biomaterials 2010;31:2990-2998.

21. Fan HB, Liu HF, Toh SL, Goh JCH. Anterior cruciate ligament regeneration using mesenchymal stem cells and silk scaffold in large animal model. Biomaterials 2009;30:4967-4977.
22. Chen X, Qi YY, Wang LL, Yin Z, Yin GL, Zou XH, Ouyang HW. Ligament regeneration using a knitted silk scaffold combined with collagen matrix. Biomaterials 2008;29:3683-3692.

23. Liu HF, Fan HB, Wang $Y$, Toh SL, Goh JCH. The interaction between a combined knitted silk scaffold and microporous silk sponge with human mesenchymal stem cells for ligament tissue engineering. Biomaterials 2008;29:662-674.

24. Chen JL, Yin Z, Shen WLA, Chen XA, Heng BC, Zou XAH, Ouyang HW. Efficacy of hESC-MSCs in knitted silk-collagen scaffold for tendon tissue engineering and their roles. Biomaterials 2010;31: 9438-9451.

25. Vaquette C, Kahn C, Frochot C, Nouvel C, Six JL, De Isla N, Luo LH, Cooper-White J, Rahouadj R, Wang XO. Aligned poly(I-lacticco-e-caprolactone) electrospun microfibers and knitted structure: A novel composite scaffold for ligament tissue engineering. J Biomed Mater Res Part A 2010;94A:1270-1282.

26. Chen GP, Sato T, Ushida T, Hirochika R, Ochiai N, Tateishi T. Regeneration of cartilage tissue by combination of canine chondrocyte and a hybrid mesh scaffold. Mater Sci Eng C Bio Supramol Syst 2004;24:373-378.

27. Dai WD, Kawazoe N, Lin XT, Dong J, Chen GP. The influence of structural design of PLGA/collagen hybrid scaffolds in cartilage tissue engineering. Biomaterials 2010;31:2141-2152.

28. Kawazoe N, Inoue C, Tateishi T, Chen GP. A cell leakproof PLGAcollagen hybrid scaffold for cartilage tissue engineering. Biotechnol Progr 2010;26:819-826.

29. $\mathrm{Ng} \mathrm{KW}, \mathrm{Khor} \mathrm{HL}$, Hutmacher DW. In vitro characterization of natural and synthetic dermal matrices cultured with human dermal fibroblasts. Biomaterials 2004;25:2807-2818.

30. Almeida LR, Martins AR, Fernandes EM, Oliveira MB, Correlo VM, Pashkuleva I, Marques AP, Ribeiro AS, Duraes NF, Silva CJ, Bonifácio G, Sousa RA, Oliveira AL, Reis RL. New biotextiles for tissue engineering: Development, characterization and in vitro celIular viability. Acta Biomater 2013;9:8167-81.

31. Kearns V, Maclntosh AC, Crawford A, Hatton PV. Silk-Based Biomaterials for Tissue Engineering. Finland: Biomaterials and Tissue Engineering Group; 2008.

32. Vepari C, Kaplan DL. Silk as a biomaterial. Progr Polym Sci 2007; 32(8-9):991-1007.

33. Correia C, Bhumiratana $S$, Yan LP, Oliveira AL, Gimble JM, Rockwood D, Kaplan DL, Sousa RA, Reis RL, Vunjak-Novakovic G. Development of silk-based scaffolds for tissue engineering of bone from human adipose-derived stem cells. Acta Biomater 2012;8:2483-92.

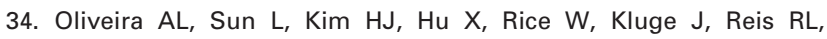
Kaplan DL. Aligned silk-based 3-D architectures for contact guidance in tissue engineering. Acta Biomater 2012;8:1530-42.

35. Silva SS, Motta A, Rodrigues MT, Pinheiro AF, Gomes ME, Mano JF, Reis RL, Migliaresi C. Novel genipin-cross-linked chitosan/silk fibroin sponges for cartilage engineering strategies. Biomacromolecules 2008;9:2764-74.

36. Yan LP, Oliveira JM, Oliveira AL, Caridade SG, Mano JF, Reis RL. Macro/microporous silk fibroin scaffolds with potential for articular cartilage and meniscus tissue engineering applications. Acta Biomater 2012;8:289-301.

37. Kardestuncer T, McCarthy MB, Karageorgiou V, Kaplan D, Gronowicz G. RGD-tethered silk substrate stimulates the differentiation of human tendon cells. Clin Orthop Relat Res 2006;448: 234-9.

38. Karthikeyan K, Sekar S, Devi MP, Inbasekaran S, Lakshminarasaiah $\mathrm{CH}$, Sastry TP. Fabrication of novel biofibers by coating silk fibroin with chitosan impregnated with silver nanoparticles. J Mater Sci Mater Med 2011;22:2721-6.

39. Sahoo S, Toh SL, Goh JC. PLGA nanofiber-coated silk microfibrous scaffold for connective tissue engineering. J Biomed Mater Res B Appl Biomater 2010;95:19-28.

40. Wu L, Li M, Zhao J, Chen D, Zhou Z. Preliminary study on polyvinyl alcohol/wild antheraea pernyi silk fibroin as nanofiber scaffolds for tissue engineered tendon. Zhongguo Xiu Fu Chong Jian Wai Ke Za Zhi 2011;25:181-6.

41. Luangbudnark W, Viyoch J, Laupattarakasem W, Surakunprapha P, Laupattarakasem P. Properties and biocompatibility of chitosan 
and silk fibroin blend films for application in skin tissue engineering. ScientificWorldJournal 2012;2012:697201.

42. Vasconcelos A, Gomes AC, Cavaco-Paulo A. Novel silk fibroin/ elastin wound dressings. Acta Biomater 2012;8:3049-60.

43. Murphy AR, Kaplan DL. Biomedical applications of chemicallymodified silk fibroin. J Mater Chem 2009;19:6443-6450.

44. Wang Y, Kim HJ, Vunjak-Novakovic G, Kaplan DL. Stem cellbased tissue engineering with silk biomaterials. Biomaterials 2006;27:6064-82.

45. Baek HS, Park YH, Ki CS, Park JC, Rah DK. Enhanced chondrogenic responses of articular chondrocytes onto porous silk fibroin scaffolds treated with microwave-induced argon plasma. Surf Coatings Technol 2008;202:5794-5797.

46. Wang S, Zhang $Y$, Wang $H$, Dong Z. Preparation, characterization and biocompatibility of electrospinning heparin-modified silk fibroin nanofibers. Int J Biol Macromol 2011;48:345-53.

47. Gu J, Yang $X$, Zhu $H$. Surface sulfonation of silk fibroin film by plasma treatment and in vitro antithrombogenicity study. Mater Sci Eng C 2002;20:199-202.

48. Jeong L, Yeo IS, Kim HN, Yoon YI, Jang DH, Jung SY, Min BM Park WH. Plasma-treated silk fibroin nanofibers for skin regeneration. Int J Biol Macromol 2009;44:222-228.

49. Murphy AR, John PS, Kaplan DL. Modification of silk fibroin using diazonium coupling chemistry and the effects on hMSC proliferation and differentiation. Biomaterials 2008;29:4260-4260.

50. Zaharia C, Tudora MR, Stanescu PO, Vasile E, Cincu C. Silk fibroin films for tissue bioengineering applications. J Optoelectron Adv Mater 2012;14(1-2):163-168.

51. Altman GH, Diaz F, Jakuba C, Calabro T, Horan RL, Chen JS, Lu H, Richmond J, Kaplan DL. Silk-based biomaterials. Biomaterials 2003;24:401-416.

52. Lu Q, Zhu HS, Zhang CC, Zhang F, Zhang B, Kaplan DL. Silk selfassembly mechanisms and control from thermodynamics to kinetics. Biomacromolecules 2012;13:826-832.

53. Owens DK, Wendt RC. Estimation of the surface free energy of polymers. J Appl Polym Sci 1969;13:1741-1747.

54. Kaelble DH. Dispersion-polar surface tension properties of organic solids. J Adhesion 1970;2:66-81.

55. Altman GH, Diaz F, Jakuba C, Calabro T, Horan RL, Chen J, Lu H, Richmond J, Kaplan DL. Silk-based biomaterials. Biomaterials 2003;24:401-16.
56. Perez-Rigueiro J, Viney C, Llorca J, Elices M. Mechanical properties of silkworm silk in liquid media. Polymer 2000;41:8433-8439.

57. Minoura N, Tsukada M, Nagura M. Physico-chemical properties of silk fibroin membrane as a biomaterial. Biomaterials 1990;11: 430-434.

58. Alves NM, Pashkuleva I, Reis RL, Mano JF. Controlling cell behavior through the design of polymer surfaces. Small 2010;6:22082220.

59. Pashkuleva I, Marques AP, Vaz F, Reis RL. Surface modification of starch based biomaterials by oxygen plasma or UV-irradiation. J Mater Sci Mater Med 2010;21:21-32.

60. Koo G-H, Jang J. Surface modification of poly(lactic acid) by UV/ Ozone irradiation. Fibers Polym 2008;9:674-678.

61. Mathieson I, Bradley RH. Improved adhesion to polymers by UV/ ozone surface oxidation. Int J Adhes Adhes 1996;16:29-31.

62. Cassie $A B$, Baxter S. Wettability of porous surfaces. Trans Faraday Soc 1944;40:546-551.

63. Gupta B, Krishnanand K, Deopura BL. Oxygen plasma-induced graft polymerization of acrylic acid on polycaprolactone monofilament. Eur Polym J 2012;48:1940-1948.

64. Chaivan P, Pasaja N, Boonyawan D, Suanpoot P, Vilaithong $T$. Low-temperature plasma treatment for hydrophobicity improvement of silk. Surf Coatings Technol 2005;193:356-360.

65. López-Pérez PM, da Silva RMP, Sousa RA, Pashkuleva I, Reis RL. Plasma-induced polymerization as a tool for surface functionalization of polymer scaffolds for bone tissue engineering: An in vitro study. Acta Biomater 2010;6:3704-3712.

66. Park K, Ju YM, Son JS, Ahn KD, Han DK. Surface modification of biodegradable electrospun nanofiber scaffolds and their interaction with fibroblasts. J Biomater Sci Polym Ed 2007;18:369-382.

67. Washburn NR, Yamada KM, Simon CG, Kennedy SB, Amis EJ. High-throughput investigation of osteoblast response to polymer crystallinity: Influence of nanometer-scale roughness on proliferation. Biomaterials 2004;25:1215-1224.

68. Arima $Y$, Iwata $H$. Effect of wettability and surface functional groups on protein adsorption and cell adhesion using welldefined mixed self-assembled monolayers. Biomaterials 2007;28: 3074-3082. 